ISSN : 2303-1514 | E-ISSN : 2598-5949

\title{
THE EFFECT OF PROBLEM BASED LEARNING ON STUDENTS' SCIENCE LEARNING ACHIEVEMENT AT GRADE IV ELEMENTARY SCHOOLS
}

\author{
Putu Beny Pradnyana ${ }^{1}$, Desak Putu Anom Janawati ${ }^{2}$, \\ ${ }^{1,2}$ Primary School Teacher Education, STKIP Suar, Bangli, Indonesia \\ ${ }^{1}$ putubenypradnyana380@gmail.com, ${ }^{2}$ desakjanawati@gmail.com
}

\section{PENGARUH PEMBELAJARAN BERBASIS MASALAH TERHADAP PRESTASI BELAJAR IPA SISWA KELAS IV SEKOLAH DASAR}

\begin{abstract}
ARTICLE HISTORY
ABSTRACT

Abstract: This research aimed at investigating the difference of science learning achievement between students studying through problem-based learning and those studying through conventional learning. 10 grade IV elementary school students were selected as research samples and they were divided into two groups: an experimental group and a control group. Those groups had been equalized by conducting Product moment analysis. This study utilized post-test only control group design. Learning achievement data were collected by using a multiple-choice test method. The test validity was examined by using Point Biserial while the

Submitted:

25 Agustus 2020

$25^{\text {th }}$ augustus 2020 test reliability was examined by using KR-20. Before testing the hypothesis, the data were processed with prerequisite test namely Normality Test (with a significance $=0.2$ ), Variant Homogeneity Test (with a significance of 0.158), Box'M Test (with a significance $=0.146$ ) and the Correlation Test between Dependent Variables / Multicollinearity (Tolerance and VIF =1). Then, the hypotheses were tested by using MANOVA (Multivariate Analysis of Variance). The research finding showed that: there was a significant difference in science learning achievement between students studying through problem-based learning and those studying through conventional learning $(F=5.574$ and sig. $=0.046 ; p<0.05)$.
\end{abstract}

Accepted:

22 Desember 2020

$22^{\text {nd }}$ December 2020

Keywords: problem-based learning, learning achievement.

Abstrak: Tujuan penelitian ini adalah untuk mengetahui perbedaan prestasi belajar IPA antara siswa yang mengikuti pembelajaran berbasis masalah dan pembelajaran konvensional. Sebanyak 10 orang siswa kelas IV Sekolah Dasar yang telah dipilih sebagai sampel penelitian yang dibagi dalam dua kelompok eksperimen dan kelompok kontrol yang sudah disetarakan dengan melakukan analisis Productmoment. Penelitian ini menggunakan desain eksperimen post-test only control group design. Data prestasi belajar dikumpulkan dengan menggunakan metode tes pilihan ganda. Uji validitas tes dianalisis dengan menggunakan Point Biserial. Uji

Published:

16 Februari 2021

$16^{\text {th }}$ February 2021 reliabilitas tes dilakukan dengan menggunakan KR-20. Data hasil penelitian dilakukan pengujian prasyarat sebelum dilakukan uji hipotesis yang diantaranya uji Uji Normalitas Data (dengan signifikansi 0.2), Uji Homogenitas Varian (dengan signifikansi 0.158), Uji Box'M (dengan signifikansi 0.146) dan Uji Korelasi Antar Variabel Terikat/Multikolinieritas (dengan Tolerance dan VIF 1) 0.2). Uji hipotesis penelitian ini menggunakan multivariate analysis of varians (MANOVA) dengan hasil penelitian menunjukkan bahwa: terdapat perbedaan prestasi belajar IPA yang signifikan antara siswa yang mengikuti pembelajaran berbasis masalah dan siswa yang mengikuti pembelajaran konvensional ( $F=5.574$ dan Sig. $=0.046 ; p<0,05)$.

Kata Kunci: Pembelajaran Berbasis Masalah, Motivasi Belajar.

CITATION

Pradnyana, P. B., \& Janawati, D. P. A. (2021). The Effect of Problem Based Learning on Students' Science Learning Achievement at Grade IV Elementary Schools. Primary: Jurnal Pendidikan Guru Sekolah Dasar, 10(1), 1-7. DOI: http://dx.doi.org/10.33578/jpfkip.v10i1.8013. 


\section{PENDAHULUAN}

Pembelajaran merupakan upaya peningkatan prestasi belajar ke arah yang lebih baik dengan memperhatikan karakteristik perkembangan anak usia sekolah dasar. Pertimbangan tersebut terkait dengan tingkat perkembangan anak usia SD yang masih dalam kategori praoprasional dan oprasional konkret, (Peaget dalam Suarni \& Gading, 2007: 64). Pada masa praoprasional dan oprasional konkret anak sudah mampu untuk memperhatikan lebih dari satu dimensi sekaligus dan juga menghubungkan dimensidimensi satu sama lain.

Tahap perkembangan praoprasional dan oprasional konkret Anak sudah memperhatikan aspek dinamisnya dalam perubahan situasi. Anak mulai mampu melakukan aktifitas logis tertentu, tetapi hanya dalam situasi yang konkrit. Dengan kata lain, jika anak dihadapkan dengan satu masalah yang abstrak, yaitu tanpa bantuan fakta konkrit, maka anak belum mampu menyelesaikan masalah yang bersifat abstrak dengan baik. Pada tahap berpikir praoprasional dan oprasional konkret, materi pelajaran yang disajikan oleh guru adalah materi-materi yang masih dekat dengan kehidupan anak, dapat dilihat, dapat dirasakan dan dapat pegang oleh siswa.

Menurut Pieget dalam Lasmawan (2010: 37) menyatakan bahwa pada tahap oprasional konkret kemampuan berpikir anak masih dalam bentuk konkret, peserta didik belum mampu berpikir secara abstrak sehingga pada tahap ini anak hanya mampu menyelesaikan soal-soal pelajaran yang bersifat konkret. Aktivitas pembelajaran yang melibatkan siswa dalam pengamalan langsung sangat efektif jika dibandingkan penjelasan guru dalam bentuk verbal atau kata-kata. Kelebihan pada tahap perkembangan ini adalah peserta didik sudah mampu memahami konsep konservasi (concept of concervacy), yaitu meskipun suatu benda berubah bentuknya, namun masa, jumlah atau volumenya adalah tetap. Peserta didik sudah mampu melakukan observasi, menilai dan mengevaluasi pada kegiatan pembelajaran berikutnya.

Kegiatan pembelajaran harus menumbuhkan interaksi peserta didik yang tidak dibatasi hanya pada penggunaan buku semata, tetapi dapat berupa pemberian masalah yang dipecahkah secara bersama-sama, namun masalah yang diberikan hendaknya dekat dengan kehidupan siswa dan tidak hanya sebatas permasalahan yang ada di buku paket melainkan pengambilan masalah sesuai dengan konteks kehidupan siswa dan pembelajaran itu seyogyanya adalah pembelajaran yang inovatif karena pembelajaran yang inovatif merupakan pembelajaran yang langsung menyentuh permasalahan dengan menghadirkan suasana baru pada proses pembelajaran, namun dalam hal ini mengkhusus pada mata pelajaran IPA (Lasmawan, 2010: 360). Untuk mengakomodasi pembelajaran yang mewakili tahap perkembangan peserta didik usia sekolah dasar yaitu tahap pra oprasional konkret, menyiapkan pembelajaran yang memberikan pengalaman langsung, inovatif dan menumbuhkan interaksi yang tidak dibatasi dapat dilakukan dengan pembelajaran berbasis masalah karena pembelajaran berbasis masalah merupakan salah satu metode dalam model pembelajaran kontekstual (Contextual Teaching and Learning) yang didasarkan pada teori belajar konstruktivisme (Pusparatri, 2012).

Salah satu pembelajaran inovatif yang dapat diterapkan adalah pembelajaran berbasis masalah, terlahir dari paham aliran pendidikan konstruktivis, yang dilatar belakangi oleh teori Pieget dan Vygotsky. Trianto (2007: 14) menyatakan teori perkembangan Pieget mewakili konstruktivisme yang memandang perkembangan kognitif sebagai suatu proses di mana anak secara aktif membangun pengetahuan dan pemahaman realita melalui pengalaman-pengalaman interaksi yang dialami oleh mereka. Penerapan pembelajaran inovatif ini mampu memberikan penilaian sikap positif oleh siswa terhadap penerapan pembelajaran berbasis masalah ini (Sari \& Rahadi, 2014), karena pembelajaran berbasis masalah ini memberikan keunggulan antara 
lain sebagai berikut: pertama merupakan teknik yang cukup baik dalam memahami isi pelajaran, kedua dapat menantang kemampuan siswa serta memberikan kepuasan untuk menemukan pengetahuan baru bagi siswa, ketiga dapat meningkatkan aktivitas siswa dalam kegiatan pembelajaran, keempat dapat membantu siswa untuk mentransfer pengetahuan untuk memahami masalah dalam kehidupan nyata, kelima dapat membantu siswa mengembangkan pengetahuan barunya dan bertanggung jawab dalam pembelajaran yang mereka lakukan sehingga dapat mendorong siswa untuk melakukan evaluasi sendiri baik terhadap hasil maupun proses belajarnya, keenam dipandang lebih mengasikkan dan disukai siswa, ketujuh dapat mengembangkan kemampuan siswa untuk berpikir kritis dan mengembangkan kemampuan mereka untuk menyelesaikan dengan pengetahuan baru dan kedelapan dapat memberikan kesempatan kepada siswa untuk mengaplikasikan pengetahuan yang telah dimiliki di dunia nyata (Lasmawan, 2010: 330)

Berbagai usaha telah dilakukan oleh guru dalam meningkatkan kualitas prestasi belajar IPA untuk memperoleh hasil yang optimal. Bila ditelusuri lebih lanjut dalam rangka perbaikan mutu pendidikan IPA sangatlah kompleks, menyangkut faktor internal dan eksternal. Berpijak pada keunggulan penerapan pembelajaran berbasis masalah maka perlu dikaji mengenai pengaruh penerapan pembelajaran berbasis masalah terhadap prestasi belajar belajar siswa. Berdasarkan pemaparan di atas, dibutuhkan pembuktian lebih lanjut dengan melakukan eksperimen mengenai "Pengaruh Pembelajaran Berbasis Masalah Terhadap Prestasi Belajar IPA Siswa Kelas IV SD Se-Desa Buahan Tabanan Bali Tahun 2018/2019"

\section{METODE PENELITIAN}

Penelitian ini merupakan penelitian eksperimen quasi atau praexperiment terjadi karena terbentur pada ketidak mampuan peneliti untuk mengontrol secara ketat variabel lain diluar variabel perlakuan, akibatnya sangat sering tidak bisa memenuhi syarat-syarat penelitian ekperimen yang sungguhan, dengan pola dasar "The Posttest-Only Control-Group Desain”. Sebanyak 10 orang siswa kelas IV SD Se-Desa Buahan dipilih sebagai sampel. Metode pengumpulan data penelitian ini menggunakan metode Tes yang sebelum sudah diuji validitas isi dan validitas konstruk instrument menggunakan Point Biserial, uji realibilitas instrument menggunakan KR-20.

Data hasil penelitian dilakukan pengujian prasyarat sebelum dilakukan uji hipotesis yang diantaranya uji Uji Normalitas Data, Uji Homogenitas Varian, Uji Box'M dan Uji Korelasi Antar Variabel Terikat/ Multikolinieritas (Candiasa, 2011: 133-199).

\section{HASIL DAN PEMBAHASAN}

Pengujian Hipotesis Pengujian hipotesis menggunakan Multivariate Analysis of Varians (MANOVA) melalui statistik $\mathrm{F}$ varians. Kriteria pengujian adalah apabila nilai F dengan signifikansi kurang dari 0.05 maka H0 ditolak, berarti terdapat perbedaan secara signifikan terhadap prestasi belajar konsep IPA dalam pembelajaran siswa kelas IV SD, yang mengikuti pembelajaran berbasis masalah dengan siswa yang mengikuti pembelajaran konvensional pada mata pelajaran IPA. Untuk pengujian hipotesis menggunakan uji analisis multivariat (MANOVA) dengan bantuan SPSS 17.00 for windows dengan hasil, sebagai berikut. 
Tabel 1. Hasil Analisis Uji Hipotesis dengan Uji Analisis Multivariat

\begin{tabular}{ccccccc}
\hline Sumber & $\begin{array}{c}\text { Variabel } \\
\text { Dependen }\end{array}$ & $\begin{array}{c}\text { Jumlah Kuadra } \\
\text { Tipe III }\end{array}$ & $\mathrm{dk}$ & $\begin{array}{c}\text { Rerata } \\
\text { Kuadrat }\end{array}$ & $\mathrm{F}$ & Sig. \\
\hline $\begin{array}{c}\text { Antar } \\
\text { kelompok }\end{array}$ & Prestasi & 285.156 & 1 & 285.156 & 5.574 & 0.046 \\
$\begin{array}{c}\text { Dalam } \\
\text { Total }\end{array}$ & Prestasi & 409.248 & 8 & 51.156 & & \\
\hline
\end{tabular}

Berdasarkan hasil analisis uji hipotesis dengan uji analisis multivariat pada Tabel, tampak bahwa koefisien $\mathrm{F}$ sebesar 5.574 dengan signifikansi (sig) sebesar 0.046 . Apabila ditetapkan taraf signifikansi $\alpha=0.05$, maka nilai signifikansi jauh lebih kecil dari pada $\alpha$ sehingga $F$ signifikan. Berdasarkan hasil uji hipotesis tersebut bahwa terdapat perbedaan yang signifikan terhadap prestasi belajar IPA antara siswa yang mengikuti pembelajaran berbasis masalah dan siswa yang mengikuti pembelajaran konvensional pada mata pelajaran IPA siswa kelas IV SD SD SeDesa Buahan Tabanan Bali.

Hasil penelitian ini menunjukan pembelajaran berbasis masalah merupakan inovasi pembelajaran yang mampu memberikan hasil yang optimal pada mata pelajaran IPA, disebabkan pembelajaran berbasis masalah merupakan teori pembelajaran beraliran konstruktivis untuk membangun (to construct) pemahamanya tentang dunia (Marhaeni, 2008: 3) yang juga mampu membangun tata susunan hidup (Riyanto, 2010: 143). Pada pembelajaran berbasis masalah yang merujuk pada aliran pembelajaran konstruktivis membuat siswa harus menemukan dan mentransformasikan pengetahuan yang kompleks, mengecek informasi baru dengan aturan-aturan lama dan merevisinya apabila aturan itu sudah tidak sesuai lagi (Trianto, 2009: 28), karena pada dasarnya setiap individu memperoleh informasi dengan menggunakan indranya, untuk melakukan interaksi dengan objek dan lingkungan, melalui melihat, mendengar, menjamah, membau atau merasakan, semakin banyak orang berinteraksi dengan objek dan lingkungannya, pengetahuan dan pemahamannya akan objek dan lingkungan tersebut akan meningkat dan lebih rinci serta pengetahuan bukanlah sesuatu yang sudah ditentukan, melainkan suatu proses pembentukan (Budiningsih, 2005: 57). Menurut Yuliana \& firmansah (2018) menemukan bahwa problem based learning with social media assistance is more effective than the conventional model to teach statistics. learning mathematics through PBL with social media assistance got a positive response from the students. Temuan tersebut menjelaskan bahwa pembelajarna berbasis masalah sangat efektif khususnya pada pelajajaran statistik, dan memberikan respon positif kepada siswa pada mata pelajaran matematika dengan bantuan sosial media. Pembelajaran berbasis masalah memiliki urutan peristiwa saat seseorang memecahkan masalah yang dimumai dengan penyajian masalah, mendefinisikan permasalahan, merumuskan hipotesa-hipotesa untuk pemecahan masalah, dan dari berbagai hipotesa-hipotesa yang muncul selanjutnya memverifikasi hipotesa untuk menemukan satu hipotesa yang berhasil mencapai pemecahannya (Dewey dalam Gagne, 1990: 231) dan pembelajaran berbasis masalah dapat membantu peserta didik untuk meningkatkan mutu pendidikan (Delisle, 1937: 13).

Juleha, Nugraha \& Feranie (2019) menemukan that students in the experimental group have a higher score in the scientific literacy test compared to the students in the control group even it was not significantly different. It is concluded that Project in problem-based learning is useful to conduct as the learning strategies in the classroom to improve students' scientific and information literacy. Ini terlihat bahwa siswa pada kelompok eksperimen memiliki nilai tes 
literasi sains yang lebih tinggi dibandingkan dengan siswa pada kelompok kontrol meskipun tidak berbeda nyata. Disimpulkan bahwa Project dalam pembelajaran berbasis masalah bermanfaat untuk dilaksanakan sebagai strategi pembelajaran di kelas untuk meningkatkan literasi sains dan informasi siswa. Melihat pembelajaran berbasis masalah merupakan pembelajaran dua arah antara belajar dan lingkungan. Lingkungan pada mata pelajaran IPA memberikan bantuan kepada setiap peserta didik untuk menyelidikan permasalahan, menilai permasalahan, menganalisis untuk menemukan pemecahan masalah yang terbaik sehingga mampu ditafsirkan oleh sistem syaraf otak. Pengalaman yang diperoleh dari lingkungan oleh peserta didik akan dijadikan sebagai bahan dan materi guna memperoleh pengertian serta bisa dijadikan pedoman dan tujuan belajarnya (Dewey dalam Trianto, 2007:67).

Sesuai dengan tahapan pembelajaran berbasis masalah diantaranya modeling, coaching, Scaffolding, fading, articulationg, reflection, exploration, tahapan tersebut disebut dengan "The stages in the cognitive apprenticeship model" (Chambers 2007: 15). Memberikan kesempatan kepada pada peserta didik se-desa buahan untuk meningkatkan prestasi belajar IPA. Untuk mengetahui peningkatan prestasi belajar IPA dilakukan melalui porses evaluasi prestasi preserta didik, diharapkan bukan hanya nilai tujuan utamanya tetapi juga untuk membantu dan memantau peningkatkan prestasinya. Guru harus mencari peserta didik yang mengalami kesulitan dengan tugas dan memberi peserta didik bantuan khusus dan saran (Delisle, 1937: 17).

$$
\text { Pada tahap modelling pada }
$$

pembelajaran IPA pendidik melaksanakan tugas dan menjelaskan mengenai yang akan dilakukan sehingga peserta didik dapat mengamati dan membangun sebuah model konseptual dalam proses yang diperlukan untuk penyelesaian. Pengetahuan dan pemahaman peserta didik diperoleh melalui pemodelan dan beberapa diantara peserta didik akan menginternalisasi proses dan mencobanya sendiri. Pada tahap ini terjadi proses pendidik untuk mendengarkan pembicaraan kelompok, perencanaan dan debat, pengajukan pertanyaan dapat guru dapat membantu peserta didik dalam mengklarifikasi pemikiran, membenarkan kesimpulan dan memperdalam pemahaman dari peserta didik. Pada tahap coaching pendidik bergabung dengan siswa ke dalam kelompok menjadi bagian dari diskusi dan membuat komentar yang bersifat membantu, mengajukan pertanyaan atau menawarkan bimbingan jika diperlukan. Pada tahap scaffolding pendidik memberikan kesempatan kepada peserta didik untuk belajar dan berkembang. Pada tahap articulation para peserta didik mengkomunikasikan hasil diskusi pengetahuannya, penalaran atau proses pemecahan masalah. Pada tahap reflection terjuadi proses membandingkan masalah mereka sendiri melalaui belajar proses pemecahan dengan para siswa lain, guru atau ahli. Pada tahap exploration para peserta didik memecahkan masalah mereka sendiri.

Tabel 2. Deksripsi Data Prestasi Belajar IPA Siswa Kelas IV SD Se-Desa Buahan Tabanan Bali

\begin{tabular}{lrrr}
\hline & \multicolumn{2}{c}{$\begin{array}{c}\text { Prestasi Belajar Kelompok } \\
\text { Kontrol }\end{array}$} & \multicolumn{2}{c}{$\begin{array}{c}\text { Prestasi Belajar Kelompok } \\
\text { Eksperimen }\end{array}$} \\
\hline $\mathrm{N} \quad$ Valid & 5 & 5 \\
& Missing & 17 & 17 \\
\hline Mean & 69.3200 & 80.0000 \\
Median & 73.3000 & 80.0000 \\
Mode & $60.00^{\mathrm{a}}$ & 80.00 \\
Minimum & 60.00 & 73.30 \\
Maximum & 80.00 & 86.70 \\
Sum & 346.60 & 400.00 \\
\hline
\end{tabular}


Jika dilihat dari Tabel 6 deksripsi data prestasi belajar IPA siswa kelas IV SD SeDesa Buahan Tabanan Bali kelompok eksperimen berkisar antara dari 73.3 sampai dengan 86.7 dengan rata-rata $\bar{X}$ sebesar 80 sedangkan nilai prestasi belajar IPA siswa kelas IV Se-Desa Buahan Tabanan Bali untuk kelompok kontrol berkisar antara 60 sampai dengan 80 dengan rata-rata $\bar{X}$ sebesar 69.32 .

Hasil penelitian ini juga didukung oleh penelitian yang dilakukan oleh Ardeniyansah \& Rosnawati Pada tahun 2018 dengan judul penelitian Implementation of Problem-Based Learning in terms of Student Mathematical Creative Thinking. Ardeniyansah dan $\mathrm{R}$ Rosnawati Menemukan bahwa PBL model is an alternative learning model that can improve students' creative thinking skills. With the $P B L$ model students are given the opportunity to think creatively. This learning model is believed to be able to improve student learning creativity. Model pembelajaran berbasis masalah dapat dijadikan alternatif model pembelajaran yang dapat meningkatkan keterampilan berpikir kreatif siswa. Dengan siswa model pembelajaran berbasis masalah diberi kesempatan untuk berpikir kreatif. Ini model pembelajaran diyakini mampu meningkatkan kreativitas belajar siswa. Hasil penelitian ini juga sejalan dengan penelitian yang dilakukan oleh Pradnyana tahun 2013 dengan judul penelitian pengaruh pembelajaran berbasis masalah terhadap motivasi belajar dan prestasi belajar matematika siswa kelas IV SD, Pradnyana menemukan bahwa pembelajaran berbasis masalah dapat memberikan motivasi yang kuat kepada peserta didik untuk belajar, pembelajaran berbasis masalah dapat memberikan kepuasan kepada peserta didik untuk menemukan pengetahuan yang baru.

\section{SIMPULAN DAN REKOMENDASI}

Terdapat perbedaan yang signifikan terhadap prestasi belajar IPA siswa kelas IV $\mathrm{SD}$, antara siswa yang mengikuti pembelajaran berbasis masalah dan siswa yang mengikuti pembelajaran konvensional pada mata pelajaran IPA.

Berdasarkan temuan hasil penelitian peneliti memberikan rekomendasi sebagai antara lain sebagai berikut: Sehubungan dengan peneliti mengambul subyek yang terbatas, maka disarankan Pertama, pembelajaran berbasis masalah memberikan efek yang positif terhadap peningkatan prestasi belajar IPA di kelas IV, sehingga kepada guru yang mengajar di kelas IV dapat menggunakan model pembelajaran berbasis masalah ini untuk meningkatkan prestasi belajar siswa khususnya pada mata pelajaran IPA. Ke-dua, kepada pihak lain untuk melakukan penelitian lanjutan tentang pembelajaran berbasis masalah pada subjek dan objek yang lebih luas, dengan berbantuan teknik yang relevan.

\section{DAFTAR PUSTAKA}

Ardeniyansah \& Rosnawati, R. (2018). Implementation of Problem-Based Learning in terms of Student Mathematical Creative Thinking. Journal of Physics: Conference Series 1097(1):012111. DOI: 10.1088/17426596/1097/1/012111.

Budiningsih, C. A. (2005). Belajar dan pembelajaran. Jakarta: Rineka Cipta

Candiasa, I Made. 2011. Statistik Multivariat Disertai Aplikasi SPSS. Singaraja: Undiksha Press.

Chambers, D. (2007). How to Succeed with Problem-Based-Learning. Australia: Carlton South.

Delisle, R. (1937). How to Use Problem-Based Learning In The Classroom. United state of America: Association for Supervision and Curriculum Development.

Gagne. R. M. (1990). Buku Petunjuk Kondisi Belajar dan Teori Pembelajaran. (Munadir, Trans). Jakarta: Dirjen Dikti Depdikbud.

Juleha,S., Nugraha, I., \& Feranie,S. (2019). The Effect Of Project In ProblemBased Learning On Students' 
Scientific And Information Literacy In Learning Human Excretory System. Journal of Science Learning. Diakses dari

https://ejournal.upi.edu/index.php/jslea rning/article/view/26.

Lasmawan, W. (2010). Menelisik Pendidikan IPS dalam Perspektif KontekstualEmpiris. Singaraja: Mediakom Indonesia Press Bali.

Marhaeni, A. A. I. N. (2008). "Pembelajaran Berbasis Asesmen Otentik dalam Rangka Implementasi Sekolah Kategori Mandiri (SKM)". Makalah. Disajikan dalam Pelatihan Peningkatan Kinerja Guru SMA 1 Kediri Tabanan, dalam Rangka Implementasi SKM; tanggal 30 Desember 2008.

Pradnyana, P. B. (2013). Pengaruh Pembelajaran Berbasis Masalah Terhadap Motivasi Belajar dan Prestasi Belajar Matematika Siswa Kelas IV SD. Jurnal Pendidikan Dasar Ganesha. Diakses dari https://www.neliti.com/id/publications/ 119603/pengaruh-pembelajaranberbasis-masalah-terhadap-motivasibelajar-dan-prestasi-be.

Pusparatri, R., \& Dewi, K. (2012). Strategi Pembelajaran Berbasis Masalah untuk Meningkatkan Kemampuan Berikir Kritis Siswa. Jurnal Ilmiah Guru “COPE" (2), 26-35.

Riyanto, H. Y. (2010). Paradigma Baru Pembelajaran sebagai Referensi bagi Pendidik dalam Implementasi Pembelajaran yang Efektif dan Berkualitas. Jakarta: Kencana.

Suarni, N. K. \& Gading. (2007). Perkembangan Peserta Didik. Fakultas Ilmu Pendidikan, Universitas Pendidikan Ganesha.

Sari, L., Permana, S., \& Rahadi, M. (2014). Pembelajarna Berbasis Masalah untuk Meningkatkan Komunikasi Matematika Siswa Sekolah Menengah
Pertama. Jurnal Pendidikan Matematika 3 (3), 143-150.

Trianto. (2007). Model-Model Pembelajaran Inovatif Berorientasi Kontruktivistik. Jakarta: Prestasi Pustaka.

Trianto. (2009). Mendesain Model Pembelajaran Inovatif-Progresif, Konsep, Landasan dan Implementasinya pada Kurikulum Tingkat Satuan Pendidikan (KTSP). Jakarta: Kencana Pranada Media Group.

Yuliana, Y., \& Firmansah, F. (2018). The Effectiveness Of Problem-Based Learning With Social Media Assistance To Improve Students' Understanding Toward Statistics. Infinity Journal. Diakses dari http://ejournal.stkipsiliwangi.ac.id/index.php/i nfinity/article/view/468. 